\title{
PREVALENCE OF HEPATITIS B AND C IN THE SERA OF PATIENTS WITH HIV INFECTION IN SÃO PAULO, BRAZIL
}

\begin{abstract}
SUMMARY
The objective of this study was to evaluate the prevalence of hepatitis B and C viruses in a group of HIV infected patients, followed at a single institution since 1996. 1,693 HIV positive patients (1,162 male, 531 female) were tested for HBV infection. Virological markers for HBV included HBsAg and total anti-HBc by ELISA. 1,457 patients (1,009 male, 448 female) were tested for HCV infection. Detection of HCV antibodies was carried out by ELISA. A sample of HCV antibody positive patients was tested for HCV by PCR to confirm infection. Of 1,693 patients tested for HBV, 654 (38.6\%) and $96(5.7 \%)$ were anti-HBc and HBsAg positive, respectively. Of 1,457 patients tested for HCV, 258 (17.7\%) were anti-HCV positive. 82 of these patients were also tested by PCR and 81 were positive (98\%). Of 1,411 patients tested for HBV and HCV $26(1.8 \%)$ were positive for both viruses.
\end{abstract}

KEYWORDS: Hepatitis C; HIV; Hepatitis B; Epidemiology

\section{INTRODUCTION}

Hepatotropic viruses that lead to chronic infection (hepatitis B virus, hepatitis $\mathrm{C}$ virus, hepatitis delta virus) and HIV share the same parenteral, sexual and vertical routes of transmission.

This common epidemiology explains the high frequency of combined infections.

There are also many important clinical interactions between human immunodeficiency virus and the hepatotropic viruses.

Limited information is available about the seroprevalence of $\mathrm{HBV} /$ $\mathrm{HCV}$ in HIV infected patients in Brazil.

The aim of this study was to assess the prevalence of HBV and HCV in the sera of a cohort of patients with HIV infection followed at a single institution.

\section{PATIENTS AND METHODS}

This study was conducted at an AIDS Outpatient Clinic, which belongs to the Division of Infectious Diseases, School of Medicine, University of São Paulo.

From January 1996 through December 1996 1,693 HIV positive patients were tested for HBV infection and 1,457 HIV positive patients were tested for HCV infection. A total of 1,411 HIV patients were tested for both viruses.

Virological markers for HBV included HBsAg and total anti-HBc by ELISA (Abbott) according to the manufacturer's instructions.

Tests for anti-HCV were done by ELISA second generation and third generation (Abbott HCV EIA), according to the manufacturer's instructions.

A sample of $\mathrm{HCV}$ antibody positive patients (82 patients) was tested for $\mathrm{HCV}$ by PCR to confirm infection.

HCV RNA was investigated by the "nested" polymerase chain reaction (PCR) using two sets of oligonucleotide primers derived from 5' non-coding region ${ }^{5,6}$. Primers PTC1 and NCR2 were designed for the outer reaction. PTC3 and NCR4 were designed for the nested reaction. Nucleotide sequences were as follows:

\author{
PTC1- 5'CGT TAG TAT GAG TGT CGT G3' \\ NCR2-5'ATA CTC GAG GTG CAC GGT CTA CGA GAC CT3’ \\ PTC3- 5'AGT GTC GTG CAG CCT CCA GG3' \\ NCR4-5'CAC TCT CGA GCA CCC TAT CAG GCA GT3'
}

(1) AIDS Outpatient Clinic, Hospital das Clínicas, School of Medicine, Infectious Diseases Department, University of São Paulo, São Paulo, SP, Brazil.

(2) Laboratório de Investigação Médica em Hepatites (LIM-47), University of São Paulo, São Paulo, SP, Brazil.

(3) Infectious Diseases Department, School of Medicine, University of São Paulo, São Paulo, SP, Brazil.

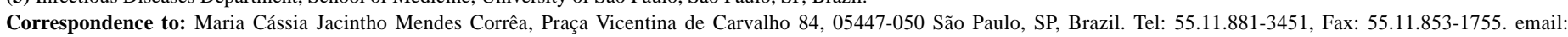
cassiamc@uol.com.br 
Risk behaviors and laboratory information presented in this study were obtained from medical records and from a computadorized data base used in follow up of these patients.

All serologic studies were performed at the Central Laboratory of Hospital das Clínicas.

PCR tests were performed at the Laboratório de Investigação Médica em Hepatites da Faculdade de Medicina da Universidade de São Paulo.

This study has received the approval of Hospital das Clinicas' Ethics Committee.

\section{RESULTS}

Among 1,693 HIV positive patients tested for HBV serologic markers $531(31.4 \%)$ were women and 1,162 (68.2\%) were men.

$654(38.6 \%)$ and $96(5.7 \%)$ were anti-HBc and HBsAg positive, respectively (Table 1).

Table 1

Prevalence of HBsAg and total anti-HBc (1,693 patients tested) and anti-HCV (1,411 patients tested)

\begin{tabular}{lcccccc}
\hline & \multicolumn{2}{c}{ POSITIVE } & \multicolumn{2}{c}{ NEGATIVE } & \multicolumn{2}{c}{ INCONCLUSIVE } \\
& Number & $\%$ & Number & $\%$ & Number & $\%$ \\
\hline HBsAg & 96 & 5.7 & 1,593 & 93.5 & 14 & 0.9 \\
Total anti-HBc & 654 & 38.6 & 1,032 & 61.0 & 7 & 0.4 \\
Anti-HCV & 258 & 17.7 & 1,180 & 81.0 & 19 & 1.3 \\
\hline
\end{tabular}

Among those patients the majority was between 31 and 40 year-old (Table 2 ).

Table 2

Patients tested for HBV infection according to age

\begin{tabular}{ccc}
\hline Age-Years & Number & $\%$ \\
\hline $0-12$ & 2 & 0.1 \\
$13-18$ & 8 & 0.5 \\
$19-25$ & 208 & 12.3 \\
$26-30$ & 395 & 23.3 \\
$31-40$ & 722 & 42.6 \\
$41-50$ & 258 & 15.2 \\
$51-60$ & 80 & 4.7 \\
$61-70$ & 20 & 1.2 \\
\hline Total & 1,693 & 100 \\
\hline
\end{tabular}

Among 1,457 HIV positive patients tested for anti-HCV 448 (30.7\%) were women and 1,009 (69.3\%) were men.
$258(17.7 \%)$ were anti-HCV positive (Table 1).

82 of these patients were also tested by PCR and 81 were positive for $\mathrm{HCV}$ virus $(98 \%)$.

Among those patients the majority was between 31 and 40 year-old (Table 3 ).

Table 3

Patients tested for HCV infection according to age

\begin{tabular}{ccc}
\hline Age-Years & Number & $\%$ \\
\hline $0-12$ & 2 & 0.1 \\
$13-18$ & 6 & 0.4 \\
$19-25$ & 194 & 13.3 \\
$26-30$ & 328 & 22.5 \\
$31-40$ & 628 & 43.3 \\
$41-50$ & 216 & 14.8 \\
$51-60$ & 66 & 4.5 \\
$61-70$ & 17 & 1.2 \\
\hline Total & 1,457 & 100 \\
\hline
\end{tabular}

251 out of these $258 \mathrm{HCV} / \mathrm{HIV}$ co-infected patients have been analyzed according to their risk factor for both infections ${ }^{10} .137(54.5 \%)$ were intravenous drug users (IDU); $40(16 \%)$ were sexual partners of HIV patients; $23(9.2 \%)$ were homosexual males, 44 (17.5\%) had promiscuous sexual habits. Intravenous drug use and sexual transmission seemed to be important modes of transmission of $\mathrm{HCV}$ infection in this group of patients (Table 4).

Table 4

Risk factors among HCV/HIV co-infected patients

\begin{tabular}{lcc}
\hline & Number & $\%$ \\
\hline Intravenous drug use & 137 & 54.5 \\
Sexual partners of HIV patients & 40 & 16 \\
Homosexual males & 23 & 9.2 \\
Promiscuous sexual habits & 44 & 17.5 \\
\hline Total patients analyzed & 251 & 100 \\
\hline
\end{tabular}

Of 1,411 patients tested for both HBV and HCV, 26 (1.8\%) were positive for both viruses.

Among this group of patients: 16 (59.5\%) were IDU; 04 (14.8\%) referred promiscuous sexual habits; $03(11 \%)$ were sexual partners of HIV patients; 2 (7.4\%) were homosexual males; 01 (3.7\%) had received blood transfusion and $3(2 \%)$ patients denied any risk factor. Two patients referred 02 different risk factors (Table 5$)^{12}$. 
Table 5

Risk factors among HBC/HCV/HIV co-infected patients

\begin{tabular}{lcc}
\hline & Number & $\%$ \\
\hline Intravenous drug use & 16 & 59.5 \\
Promiscuous sexual habits & 04 & 14.8 \\
Sexual partners of HIV patients & 03 & 11.1 \\
Homosexual males & 02 & 7.4 \\
Denied any risk factor & 03 & 11.1 \\
Blood transfusion & 01 & 3.7 \\
Patients with more than one risk factor & 02 & \\
\hline
\end{tabular}

\section{DISCUSSION}

HCV, HBV and HIV share the same routes of transmission.

Therefore the prevalence of antibodies to HBV and HCV in HIV infected patients varies according to the risk factor involved for the acquisition of these infections and to the serological assay used ${ }^{11}$.

Initially, the prevalence of $\mathrm{HCV}$ antibodies in HIV positive patients was overestimated by the frequent false-positive results of the first generation assays ${ }^{23}$.

The prevalence of antibodies to $\mathrm{HCV}$ and $\mathrm{HBV}$ may also be underestimated by their fluctuations or spontaneous disappearance in HIV seropositive patients ${ }^{15,23}$.

WOOLEY et al. analyzed the sera of fifty-two HIV infected patients with transaminase levels greater than twice the normal value and with negative tests for hepatitis B surface antigen and hepatitis $\mathrm{C}$ antibody. Eleven out of 52 patients $(21 \%)$ had HBVDNA in plasma. All these patients carried anti-HBc. Eighteen out of $52(35 \%)$, negative for anti$\mathrm{HCV}$, had HCV-RNA in plasma by polymerase chain reaction test ${ }^{22}$.

In one study, more than $90 \%$ of patients with HIV infection had HBV markers of current or past infection'.

Among HIV infected hemophiliacs the prevalence of anti-HCV varies between $60 \%$ to $95 \%$, and, among HIV infected intravenous drug users, it may be around $70 \%{ }^{11,23}$.

$\mathrm{HCV}, \mathrm{HBV}$ and HIV are transmitted by parenteral routes, and coinfection with these viruses is common among patients with a history of intravenous drug use or transfusion. HBV and HIV can also be transmitted by sexual intercourse.

Sexual transmission of $\mathrm{HCV}$ has been a matter of important controversy in literature ${ }^{21}$.

Case-control studies have reported an association between a sexual contact with a patient with a history of hepatitis or exposure to multiple sexual partners and the acquisition of hepatitis $\mathrm{C}^{2}$.
Some studies have suggested that the level of HCV viremia is higher in HIV-infected patients when compared to HIV-negative patients ${ }^{23}$. It is possible that sexual transmission of HCV could be enhanced in HIVpositive patients due to higher HCV viremia.

The present study showed that among 1,457 HIV-infected patients, $17.7 \%$ (258) were co-infected by HCV. It also showed that 81 out of 82 anti-HCV patients also tested by PCR were positive for HCV virus (98\%). This result could suggest that HIV/HCV co-infected patients are very likely to have active HCV infections with persistent viremia.

251 out of these $258 \mathrm{HCV} / \mathrm{HIV}$ co-infected patients have been analyzed according to their risk factor for both infections (Table 4). Intravenous drug use and sexual transmission seemed to be important modes of transmission of $\mathrm{HCV}$ infection in our group of patients.

Our study also showed that out of 1,693 HIV-infected patients, $38.6 \%$ (654) and 5.7\% (96) were anti-HBc and $\mathrm{HBsAg}$ positive, respectively.

Also according to our study, out of 1,411 patients tested for both $\mathrm{HBV}$ and HCV, 26 (1.8\%) were positive for both viruses. This group of patients have been analyzed according to their risk factors for HIV/HCV/ HBV (Table 5). Intravenous drug use was the most important risk factor involved in this situation.

We should bear in mind that the true seroprevalence of HBV and $\mathrm{HCV}$, in the population we studied, may be even more expressive than the one we have found, due to limitations of the serological methods.

As we pointed out before, a single negative antibody assay is not sufficient to exclude HCV or HBV in HIV positive patients. Loss of reactivity to antigens has been described in other forms of immunosuppression such as transplant recipients or patients on chronic hemodialysis ${ }^{20}$.

However the seroprevalences of $\mathrm{HBV}$ and $\mathrm{HCV}$ in this population of HIV positive patients, are much higher than the prevalences of these viruses among blood donors or in the general population, in Brazil ${ }^{1}$.

Such high seroprevalences are easy to understand when we analyze the epidemiology of HIV infection in Brazil.

An evolving pattern in the epidemiology of HIV infection has become evident in most countries of the Americas, including Brazil.

Substantial differences in the distribution of cases, according to the exposure category, have been observed in the present decade when compared to the early 1980 s.

Initially, in Brazil, the epidemic affected mainly male homosexuals or bisexuals, hemophiliacs and others who had received blood products.

However, within the past few years, there has been an increase of HIV infection among intravenous drug users and heterosexuals ${ }^{17}$.

Intravenous drug use is responsible at present for about $20 \%$ of accumulated AIDS cases in Brazil ${ }^{4}$. 


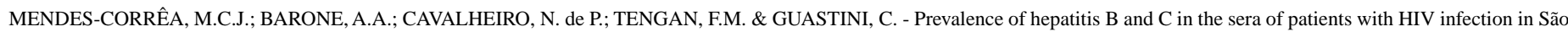
Paulo, Brazil. Rev. Inst. Med. trop. S. Paulo, 42(2): 81-85, 2000.

Therefore intravenous drug use has become an important risk factor for acquisition of HIV, in Brazil. For this reason it is easy to understand the high prevalence for HBV and HCV among our group of HIV infected patients, in São Paulo.

TREITINGER et al. studied the seroprevalence for HBV and HCV in 93 HIV positive patients in Santa Catarina (Brazil). Among 34 intravenous drug users $\mathrm{HBV}$ and $\mathrm{HCV}$ prevalences were $85.3 \%$ and $88.2 \%$ respectively ${ }^{19}$.

There are many important clinical interactions between human immunodeficiency virus and these hepatotropic virus ${ }^{3,7}$.

In regard to the effects of HIV infection on hepatitis B, HIV seropositivity has been associated with significantly lower ALT levels, higher serum levels of DNA or DNA polymerase, lower serum DNA clearance rates and milder hepatic histologic changes ${ }^{8}$.

Patients co-infected with both HIV and HCV have a higher risk of progression to chronic liver disease than those infected with $\mathrm{HCV}$ alone ${ }^{13,14,18}$. Also, increased hepatotoxicity due to protease inhibitors has been reported in co-infected patients ${ }^{16}$.

Clinicians should be aware of those possible interactions.

We believe our data could help health professionals to deal better with HIV infected patients.

We also believe our data reinforces the need of prevention programs on HIV transmission.

\section{RESUMO}

\section{Prevalência das hepatites $\mathrm{B}$ e $\mathrm{C}$ em pacientes infectados pelo virus da imunodeficiência humana, em São Paulo, Brasil}

O objetivo do presente trabalho é avaliar a prevalência da infecção causada pelos vírus da hepatite B (HBV) e da hepatite C (HCV) em um grupo de pacientes infectados pelo HIV e acompanhados em uma única instituição desde 1996. 1.693 pacientes infectados pelo HIV (1.162 do sexo masculino e 531 do sexo feminino) foram testados para o HBV. Os marcadores virológicos utilizados para o HBV foram o HBsAg e o anti$\mathrm{HBc}$ total por ELISA. 1.457 pacientes (1009 do sexo masculino e 448 do sexo feminino) foram testados para o HCV. Realizou-se a detecção dos anticorpos para o HCV através da reação de ELISA. Um grupo de pacientes anti-HCV positivos realizou PCR (polimerase chain reaction) para pesquisa do HCV, para confirmação da infecção. Dos 1.693 pacientes testados para HBV, $654(38,6 \%)$ e $96(5,7 \%)$ eram anti-HBc total e HBsAg positivos, respectivamente. Dos 1.457 pacientes testados para HCV, $258(17,7 \%)$ eram anti-HCV positivos. 82 desses pacientes realizaram PCR para HCV e 81 foram positivos (98\%). Dos 1.411 pacientes testados para ambos os vírus HBV e HCV 26 (1,8\%) foram positivos para ambos os vírus.

\section{ACKNOWLEDGMENT}

We thank Professor David Uip, Chief, AIDS Outpatient Clinic, University of São Paulo.
This work was presented in part at the $38^{\text {th }}$ Interscience Conference on Antimicrobial Agents and Chemotherapy, San Diego, California, U.S.A., 1998.

\section{REFERENCES}

1. CARRILHO, F.J. \& MENDES-CORRÊA, M.C.J. - The magnitute of hepatitis B and C in Latin America. In: SCHINAZI, R.F.; SOMMADOSSI, J.P. \& THOMAS, H.C., ed. Therapies for viral hepatitis. London, International Medical Press, 1998. p. 25 34.

2. CENTERS FOR DISEASE CONTROL AND PREVENTION - Recommendations for prevention and control of hepatitis $\mathrm{C}$ virus $(\mathrm{HCV})$ infection and $\mathrm{HCV}$-related chronic disease. MMWR, 47: 1-39, 1998.

3. COLIN, J.F.; CAZALS-HATEM, D.; LORIOT, M.A. et al. - Influence of immunodeficiency virus infection on chronic hepatitis. Hepatology, 29: 1306-1310, 1999.

4. FONSECA, M.G.P. \& CASTILHO, E.A. - Os casos de AIDS entre usuários de drogas injetáveis, Brasil, 1980-1997. Bol. Epidem. AIDS, 10(3): 6-14, 1997.

5. GARSON, J.A.; TEDDER, R.S.; BRIGGS, M. et al. - Detection of hepatitis C viral sequences in blood donations by "nested" polymerase chain reaction and prediction of infectivity. Lancet, 335: 1419-1422, 1990.

6. GARSON, J.A.; RING, C.; TUKE, P. \& TEDDER, R.S. - Enhanced detection by PCR of hepatitis C virus RNA. Lancet, 336: 878-879, 1990a.

7. GILSON, R.J.; HAWKINS, A.E.; BEECHAM, M.R. et al. - Interactions between HIV and hepatitis B virus in homosexual men: effects on the natural history of infection. AIDS, 11: 597-606, 1997.

8. HORVATH, J. \& RAFFANTI, S.P. - Clinical aspects of the interactions between human immunodeficiency virus and the hepatotropic viruses. Clin. infect. Dis., 18: 339347,1994 .

9. LEBOVICS, E.; DWORKIN, B.; HEIER, S. \& ROSENTHAL, W. - The hepatobiliary manifestations of human immunodeficiency virus infection. Amer. J. Gastroent., 83: $1-7,1988$.

10. MENDES-CORRÊA, M.C.J. - Prevalence of hepatitis B and C in HIV positive Brazilian patients. In: INTERSCIENCE CONFERENCE ON ANTIMICROBIAL AGENTS AND CHEMOTHERAPY, 38., San Diego, 1998. Program and abstracts. p. 326, H-37.

11. MENDES-CORRÊA, M.C.J. - Infecção pelo vírus da hepatite $\mathrm{C}$ em pacientes infectados pelo HIV. Aspectos epidemiológicos, clínicos e terapêuticos. Folha méd., 117: 13$16,1998$.

12. MENDES-CORREAA, M.C.J; SILVA, A.C.M.; GUASTINI, C.F. \& BARONE, A.A. Co-infecção pelos vírus das hepatites B e C em pacientes infectados pelo vírus da imunodeficiência humana, na cidade de São Paulo. Características clínicas e laboratoriais. In: CONGRESSO DA SOCIEDADE BRASILEIRA DE MEDICINA TROPICAL, 36, São Luís/Maranhão, 2000. Resumos. p. 360, 69TL.

13. SABIN, C.A.; TELFER, P.; PHILLIPS, N.A. et al. - The association between hepatitis C virus genotype and human immunodeficiency virus disease progression in a cohort of hemophilic men. J. infect. Dis., 175: 164-168, 1997.

14. SOTO, B.; SANCHEZ-QUIJANO, A.; RODRIGO, L. et al. - Human immunodeficiency virus infection modifies the natural history of chronic parenterally-acquired hepatitis $\mathrm{C}$ with an unusually rapid progression to cirrhosis. J. Hepat., 26: 1-5, 1997.

15. SPENGLER, U. \& ROCKSTROH, J.K. - Hepatitis C in the patient with human immunodeficiency virus infection. J. Hepat., 85: 1023-1030, 1998. 
16. SULKOWSKI, M.S.; THOMAS, D.L.; CHAISSON, R.E. \& MOORE, R.D. Hepatotoxicity associated with antiretroviral therapy in adults infected with human immunodeficiency virus and the role of hepatitis C or B virus infection. J. Amer. med. Ass., 283: 74-80, 2000.

17. SZWARCWALD, C.L.; BASTOS, F.I. \& CASTILHO, E.A. - The dynamics of the AIDS epidemic in Brazil: a space-time analysis in the period 1987-1995. Braz. J. infect. Dis., 2: 175-186, 1998

18. TELFER, P.; SABIN, C.; DEVEREUX, H. et al. - The progression of HCV-associated liver disease in a cohort of haemophilic patients. Brit. J. Haemat., 87: 555-561, 1994.

19. TREITINGER, A.; SPADA, C.; SILVA, E.L. et al. - Prevalence of serologic markers of HBV and HCV infection in seropositive patients in Florianópolis, Brazil. Braz. J. infect. Dis., 3: 1-5, 1999
20. VATHSAlA, A. - Viral hepatitis in renal transplantation. Transplant. Proc., 31: 337 $339,1999$.

21. WEJSTAL, R. - Sexual transmission of hepatitis C virus. J. Hepat., 31(suppl. 1): 92-95, 1999.

22. WOOLEY, I; VALDEZ, H.; HORSCH, A. et al. - Prevalence of unrecognized hepatitis B and $\mathrm{C}$ infections in AIDS patients with abnormal liver function tests. In: CONFERENCE ON RETROVIRUS AND OPPORTUNISTIC INFECTIONS, 6. Chicago, 1999. Program and abstracts. Abstract 189.

23. ZYLBERBERG, H. \& POL, S. - Reciprocal interactions between human immunodeficiency virus and hepatitis C virus infections. Clin. infect. Dis., 23: 1117-1125, 1996.

Received: 18 November 1999

Accepted: 17 March 2000 